\title{
Rediscovery of Brazilian corambids (Gastropoda: Onchidorididae)
}

\author{
CARLO M. CUNHA ${ }^{1,2}$, LUIZA O. SAAD ${ }^{3}$ AND PATRÍCIA O.V. LIMA ${ }^{4,5}$ \\ ${ }^{1}$ Academy of Natural Sciences, 1900 Benjamin Franklin Parkway, Philadelphia, PA 19103, USA, ${ }^{2}$ Capes Foundation, Ministry of \\ Education of Brazil, Brasília/DF 70040-020, Brazil, ${ }^{3}$ Universidade Estadual Paulista, Campus Experimental do Litoral Paulista- \\ UNESP, 11330-900, São Vicente, SP, Brazil, ${ }^{4}$ Instituto de Biociências, Universidade de São Paulo, Rua do Matão, trav. 14, ${ }^{\circ} 321$, \\ Cidade Universitária, São Paulo-SP, CEP: 05508-09o, ${ }^{5}$ Museu de Zoologia da USP, Cx. Postal 42494, 04299-970 São Paulo, SP, \\ Brazil
}

Three specimens of the genus Corambe were found in the intertidal zone of Santos, São Paulo (Brazil); two of them were identified as $\mathrm{C}$. evelinae and one as C. carambola. Both species are reported for the first time since more than about 40 years ago.

Keywords: biodiversity, Corambe, Gastropoda, Nudibranchia, Brazil

Submitted 15 May 2013; accepted 8 January 2014

\section{INTRODUCTION}

Current knowledge about Brazilian opisthobranchs is mostly derived from the taxonomic studies of Ernst and Eveline Marcus on material from the intertidal zone of São Paulo State and a few samples from other regions of the Brazilian coast (e.g. Marcus, 1955, 1957, 1970). As is the case for other species described by Ernst Marcus (e.g. Plocamopherus gulo Marcus, 1979), Corambe carambola (Marcus, 1955) and C. evelinae Marcus, 1956 have never been collected again since their original description (Martynov \& Schrödl, 2011). This is partly because corambids are very small animals, living camouflaged under rocks, and because of a lack of collections featuring them. However, recent efforts by researchers, especially in the last two decades, conducting new faunal surveys have brought to light poorly known species (Padula \& Santos, 2006; Lima \& Delgado, 2011; Padula et al., 2011, 2012) and updated the Brazilian opisthobranch fauna with the description (Pola et al., 2005; DaCosta et al., 2007; Domínguez et al., 2006a, b, 2008; Padula \& Delgado, 2010; Alvim et al., 2011; Cunha, 2011; Silva et al., 2013; Alvim \& Pimenta, 2013).

During collection along the rocky shore of Santos Bay (São Paulo State, Brazil) three specimens of the onchidoridid genus Corambe were collected. Corambids comprise fewer than 20 species (Martynov, 1994) and are considered aberrant or primitive dorid nudibranchs owing to their singular morphology (Schrödl \& Wägele, 2001). They have a flat oval shape, posteroventral gills formed by a thin lamellar layer, the anus located between the gills, a notal cuticle, a lobed digestive gland, a dorsoventral septa and a peculiar circulatory system (Martynov \& Schrödl, 2011). The species are small (usually 5-10 mm), mainly found under or on rocks in littoral and sublittoral temperate waters, and most of them feed on encrusting bryozoans (Yoshioka, 1986; Valdés \& Bouchet, 1998).

One of our collected specimens was identified as C. carambola (Marcus, 1955) and the other as C. evelinae Marcus, 1958. Thus, in this contribution C. carambola (Marcus, 1955) is recorded for the first time after Marcus (1970) and C. evelinae Marcus, 1958 is recorded for the first time after their original descriptions; also photographs of both the living specimens of these species are presented.

\section{MATERIALS AND METHODS}

\section{Study area}

Santos Bay (Figure $1 \mathrm{~A}, \mathrm{~B}$ ), is located on the coast of the State of São Paulo, Brazil $\left(23^{\circ} 30^{\prime} 5^{\prime \prime} \mathrm{S}-24^{\circ} \mathrm{S} 46^{\circ} 05^{\prime} \mathrm{W}-46^{\circ} 30^{\prime} \mathrm{W}\right)$, part of the Santos and São Vicente Estuarine System (Figure $1 \mathrm{~B}$ ) and it shelters part of the Baixada Santista Metropolitan Region. The Santos and São Vicente Estuarine Systems are surrounded by mangroves which make up $43 \%$ of the total mangrove area of São Paulo (Lamparelli et al., 2001; Cesar et al., 2009). Despite the area's ecological importance, it is a densely urbanized region, containing the Port of Santos (a major Latin American port) and it houses the biggest Brazilian industrial complex, consisting predominantly of petrochemical, siderurgy, and fertilizer industries (Boldrini \& Navas-Pereira, 1987; Abessa et al., 2001; Lamparelli et al., 2001; Cesar et al., 2006, 2009).

The study area is a rocky shore consisting of a continuous range of small and medium stones that can be easily lifted. This area ranges from $1-3 \mathrm{~m}$ spread and extends $\sim_{3} \mathrm{~km}$ along the entrance channel of the port of Santos, in São Vicente Island (Figure $1 \mathrm{~B}$ ). The specimens were found in a specific locality (Figure $1 \mathrm{C}$ ) in this area. 


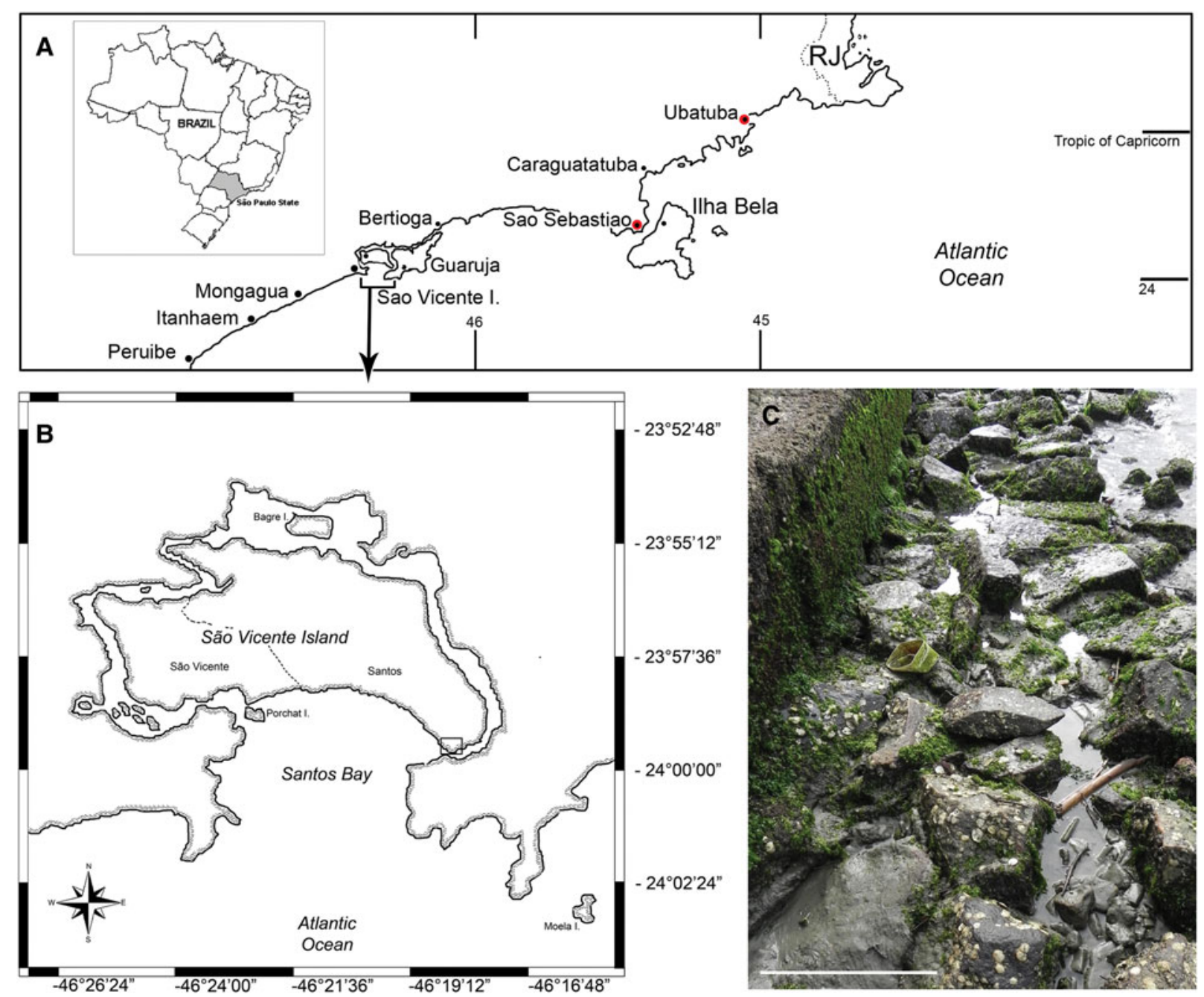

Fig. 1. Study area: (A) map of north coast of São Paulo, São Paulo State, Brazil; (B) map detail of the rock shore position located in São Vicente Island, Santos Bay; (C) rock shore area where the specimens were found. RJ, Rio de Janeiro State; red dots, type localities. Scale bar: $\mathrm{C}=100 \mathrm{~mm}$.

\section{Collection and material processing}

Both C. carambola and C. evelinae were collected during the low tide and were living actively under rocks encrusted by the bryozoan Biflustra denticulata (Busk, 1856), on the rocky shore of Santos Bay, São Paulo State, Brazil.

The specimens were taken to the laboratory, analysed, photographed under a stereomicroscope, and deposited in the following institutions: Museu de Zoologia da Universidade de São Paulo (MZSP; São Paulo, Brazil); and Zoologische Staatssammlung München (ZSM Mol; Munich, Germany). The external morphology of both species agrees with the original descriptions.

\section{RESULTS}

SYSTEMATICS

NUDIBRANCHIA Cuvier, 1817

Family ONCHIDORIDIDAE Gray, 1827

Corambe Bergh, 1869

Corambe carambola (Marcus, 1955)

(Figures 2 A-D)
Corambella carambola, Marcus, 1955: 163-167, figures 209217.

Corambe carambola, Martynov \& Schrödl, 2011: 587-600, tables 1 \& 2, figures 3 \& 4; Bouchet, 2013.

Doridella carambola, Marcus, 1970: 210; Abbott, 1974: 365; Rios, 1985: 187, pl. 66, figure 951, 1994: 209, pl. 71, figure 1015 .

Corambe obscura, Swennen \& Dekker, 1995: 105, table 2 (in part); Rios, 2009: 412, unnumbered figure of same drawing of original description of C. carambola; Rosenberg, 2009 (in part) [non Verrill, 1870].

TYPE LOCALITY

Ubatuba and São Sebastião Island, São Paulo, Brazil (Figure 1A).

\section{DISTRIBUTION}

So far, São Paulo (Brazil).

\section{MATERIAL EXAMINED}

Under rocks encrusted by the bryozoans Biflustra denticulata (Busk, 1856) at low tide, Brazil; São Paulo, Santos, Ponta da Praia, $23^{\circ} 59^{\prime} 29.37^{\prime \prime} \mathrm{S} 46^{\circ} 18^{\prime} 16.26^{\prime \prime} \mathrm{W}$, MZSP 111021 (Figure $2 \mathrm{~A}-$ D), 1 specimen (living $4.2 \mathrm{~mm}$ long, Cunha col. 2 August 2011). 


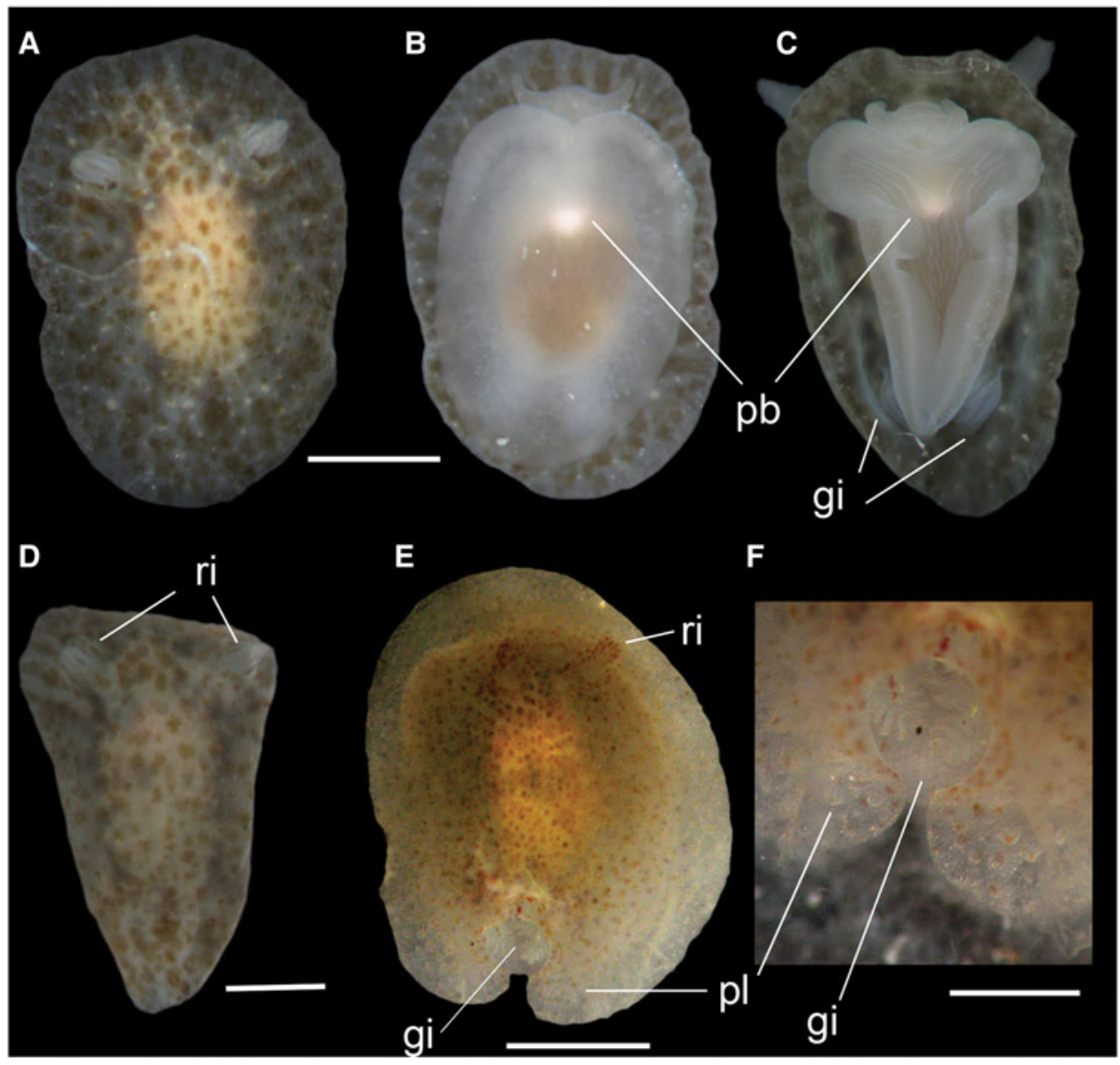

Fig. 2. Brazilian corambids: Corambe carambola: (A) dorsal view of living specimen (MZSP 111021), with notum and foot expanded; (B) same, ventral view, with notum and foot expanded; (C) same, contracted; (D) same view of (A), but with notum and foot contracted; Corambe evelinae, (E) dorsal view of living specimen (MZSP 111020); (F) same specimen, detail of posterior notch. gi, gills; ri, rhinophores; pb, circular bright white patch; pl, posterior notal lobes. Scale bars: $\mathrm{E}=$ $3 \mathrm{~mm} ; \mathrm{F}=1 \mathrm{~mm} ; \mathrm{A}-\mathrm{D}=2 \mathrm{~mm}$.

\section{REMARKS}

This species was reported after its original description (from Ubatuba and São Sebastião Island, São Paulo State, Brazil) only once more, from Cananéia (southern São Paulo, about $300 \mathrm{~km}$ to the south of the type locality), by Marcus (1970: 210, as Doridella carambola). Afterwards, it was cited in Abbott's (1974: 365) and Riośs catalogues (1985: 187, pl. 66, figure 951; 1994: 209, pl. 71, figure 1015), also as D. carambola. Although many authors have afterwards treated $C$. carambola as a synonym of $C$. obscura (Swennen \& Dekker, 1995; Rios, 2009; Rosenberg, 2009), Martynov \& Schrödl (2011) recently revealed considerable differences between both species and regarded $C$. carambola as a valid species.

When analysed alive under a stereomicroscope the specimens of C. carambola which were observed to have a small $(\sim 0.3 \mathrm{~mm})$ circular bright white ventral patch (Figure $2 \mathrm{~B}, \mathrm{C}$ ). This feature, also observed by Dr Michael Schrödl (personal communication) in specimens of $C$. cf carambola from Pernambuco (northeastern Brazil) had not been reported previously.

As Corambe carambola were found upon a colony of the encrusting bryozoans Biflustra denticulate, this could suggest a predator-prey relationship with this species, although Marcus (1970) reports specimens of C. carambola from Cananéia (southern São Paulo) living upon hydrozoans.
Corambe evelinae Marcus, 1958

(Figures $2 \mathrm{E}-\mathrm{F}$ )

Corambe evelinae, Marcus, 1958: 53-56, figures 50-55; Abbott, 1974: 365; Rios, 1985: 187, pl. 65, figure 946, 1994: 209, pl. 71, figure 1014, 2009: 421, unnumbered figure of same drawing of original description; Martynov \& Schrödl, 2011: 587-599, table 2, figures 3 \& 4; Martynov et al., 2011: 130-140; Rosenberg, 2013.

Neocorambe evelinae, Swennen \& Dekker, 1995: 105, table 2.

\section{MATERIAL EXAMINED}

Under rocks encrusted by the bryozoans Biflustra denticulate (Busk, 1856) at low tide, Brazil; São Paulo, Santos, Ponta da Praia, $23^{\circ} 59^{\prime} 29.37^{\prime \prime} \mathrm{S} 46^{\circ} 18^{\prime} 16.26^{\prime \prime} \mathrm{W}$, MZSP 111020 (Figure $2 \mathrm{E}$, F), 1 specimen (living $8.0 \mathrm{~mm}$ long, Cunha \& Saad col. 26 July 2010), ZSM Moll 20120182, 1 specimen (living $7.4 \mathrm{~mm}$ long, Cunha \& Saad col. 10 September 2010).

\section{TYPE LOCALITY}

Ubatuba, São Paulo, Brazil (Figure 1A).

\section{DISTRIBUTION}

So far, São Paulo (Brazil). 


\section{REMARKS}

Although this species has been included in the Abbot (1974: 365) and Rios' catalogues (1985: 187, pl. 65, figure 946; 1994: 209, pl. 71, figure 1014; 2009: 421), and more recently quoted in the Martinov \& Schrödl (2011) and Martynov et al. (2011) contributions, this is the first record of the species after its original description, from the city of Ubatuba in the State of São Paulo, Brazil.

As in the case of Corambe carambola, a predator-prey relationship with the bryozoan Biflustra denticulata could be suggested.

\section{ACKNDWLEDGEMENTS}

Our thanks to Barbara Louise (Brazil) and Lucas Cervera (Spain) for lending valuable reference material; to Rodrigo B. Salvaror for the English revision and helpful comments; and to Leandro M. Vieira for the identification of the bryozoan. We thank Michael Schrödl (Germany) for further comments on the manuscript. This work was partially supported by Fundação de Amparo a Pesquisa do Estado de São Paulo (FAPESP) procs. No. 2010/11253-9 (CMC) and No. 2011/ 01493-5 (LOS) and the Capes Foundation, Bolsista da CAPES proc. No. 8739/13-7 (CMC).

\section{REFERENCES}

Abbott R.T. (1974) American seashells. 2nd edition. New York: Van Nostrand Reinhold Company, $663 \mathrm{pp}+24 \mathrm{pls}$.

Abessa D.M.S., Sousa E.C.P.M., Rachid B.R.F. and Mastroti R.R. (2001) Sediment toxicity in Santos estuary, SP-Brazil: preliminary results. Ecotoxicology and Environmental Restoration 4, 6-9.

Alvim J., Padula V. and Pimenta A.D. (2011) First record of the genus Onchidoris (Gastropoda: Nudibranchia: Onchidorididae) from the South Atlantic Ocean, with the description of a new species from Brazil. Journal of the Marine Biological Association of the United Kingdom 91, 505-511.

Alvim J. and Pimenta A.D. (2013) Taxonomic review of the family Discodorididae (Mollusca: Gastropoda: Nudibranchia) from Brazil, with descriptions of two new species. Zootaxa 3745, 152-198.

Bergh L.S.R (1869) Bidrag til en Monographi af Phyllidierne. Naturhistorisk Tidsskrift Stiftet af Henrik Kr øyer. Kjöbenhavn 3, 357-542.

Boldrini C.V. and Navas-Pereira D. (1987) Metaispesados na Baía de Santos e Estuários de Santos e São Vicente: Bioacumulação. Ambiente 1, 118-127.

Bouchet P. (2013) Corambe carambola (Marcus, 1955). World Register of Marine Species. Available at: http://www.marinespecies.org/aphia. php? $\mathrm{p}=$ taxdetails\&id=582156 (accessed 12 August 2012).

Cesar A., Pereira C.D.S., Santos A.R., Abessa D.M.S., Fernández N., Choueri R.B. and DelValls T.A. (2006) Ecotoxicological assessment of sediments from the Santos and São Vicente estuarine systemBrazil. Brazilian Journal of Oceanography 54, 55-63.

Cesar A., Abessa D.M.S., Pereira C.D.S., Santos A.R., Fernández N., Choueri R.B. and DelValls T.A. (2009) A simple approach to integrate the ecotoxicological and chemical data for the establishment of environmental risk levels. Brazilian Archives of Biology and Technology 52, 233-240.

Cunha C.M. (2011) A new species of Acteon (Opisthobranchia: Acteonidae) from Northeast Brazil. Zoologia 28, 229-232.
Cuvier G.L.C.F.D. (1817) Le Règne Animal, distribué d'après son organisation, pour servir de base à l'histoire naturelle des animaux et d'introduction à l'anatomie comparée, tome II, contenant les reptiles, les poissons, les mollusques et les annelids. Paris: Deterville, xviii +532 pp.

DaCosta S., Cunha C.M., Simone L.R. and Schrödl M. (2007) Computer-based 3-dimensional reconstruction of major organ systems of a new aeolid nudibranch subspecies, Flabellina engeli lucianae, from Brazil (Gastropoda: Opisthobranchia). Journal of Molluscan Studies 73, 339-353.

Domínguez M., García F.J. and Troncoso J. (2006a) Some aspects of the family Chromodorididae (Opisthobranchia: Nudibranchia) from Brazil, with description of a new species. Scientia Marina 70, 621-634.

Domínguez M., García F.J. and Troncoso J. (2006b) A new species of Hoplodoris Bergh, 1880 (Gastropoda: Opisthobranchia: Nudibranchia) from the Atlantic Ocean. Nautilus 120, 150-155.

Domínguez M., Troncoso J. and García F.J. (2008) The family Aeolidiidae Gray, 1827 (Gastropoda, Opisthobranchia) from Brazil, with a description of a new species belonging to the genus Berghia Trinchese, 1877. Zoological Journal of the Linnean Society 153, 349-368.

Gray J.E. (1827) Plate Mollusca [= plate3]. In Smedley E., Rose H.J. and Rose H.J. (eds) (1845) Encyclopaedia Metropolitana 7. London: B. Fellows, plates to zoology.

Lamparelli M.L., Costa M.P., Prósperi V.A., Bevilácqua J.E., Araújo R.P.A., Eysink G.G.L. and Pompéia S. (2001) Sistema estuarino de Santos e São Vicente. São Paulo: Relatório Técnico CETESB, 178 pp.

Lima P.O.V. and Delgado M. (2011) First occurrence of Crosslandia daedali (Nudibranchia: Dendronotacea) in the South Atlantic, Northeast Brazil. Strombus 18, 13-14.

Marcus E. (1955) Opisthobranchia from Brazil (1). Boletim da Faculdade de Filosofia, Ciências e Letras, Universidade de São Paulo, Zoology 20, 89-261.

Marcus E. (1957) On Opisthobranchia from Brazil (2). Journal of the Linnean Society of London 43, 390-486.

Marcus E. (1958) Notes on Opisthobranchia. Boletim da Instituto Oceanográfico São Paulo 7, 31-78 [1956].

Marcus E. (1970) On some opisthobranchs from Cananéia, Brazil. Boletim Zoologia e Biologia Marinha, Universidade de São Paulo 27, 207-228.

Martynov A.V. (1994) Materials for the revision of the nudibranch molluscs of the family Corambidae (Gastropoda, Opisthobranchia) Part 1. Taxonomy. Zoologichesky Zhurnal 73, 1-15.

Martynov A.V. and Schrödl M. (2011) Phylogeny and evolution of corambid nudibranchs (Mollusca: Gastropoda). Zoological Journal of the Linnean Society 163, 585-604.

Martynov A.V., Brenzinger B., Hooker M.Y. and Schrödl M. (2011) 3D anatomy of a new tropical Peruvian nudibranch gastropod species, Corambe mancorensis, and novel hypothesis on dorid gill ontogeny and evolution. Journal of Molluscan Studies 77, 129-141.

Padula V. and Delgado M. (2010) A new species of Cerberilla (Gastropoda: Nudibranchia: Aeolidiidae) from northeastern Brazil. Nautilus 124, 175-180.

Padula V., Bahia J., Vargas C. and Lindner A. (2011) Mollusca, Nudibranchia: new records and southward range extensions in Santa Catarina, southern Brazil. Check List 7, 806-808.

Padula V., Bahia J., Correia M.D. and Sovierzoski H. (2012) New records of opisthobranchs (Mollusca: Gastropoda) from Alagoas, north-eastern Brazil. Marine Biodiversity Records 5, e7 1-11. DOI: http://dx.doi.org/10.1017/S1755267212000346.

Padula V. and Santos F.N. (2006) Three new records of nudibranchia (Mollusca, Gastropoda)-additions on the Brazilian biodiversity. Biociências 14, 214-220. 
Pola M., Cervera J.L. and Gosliner T.M. (2005) A new species of Tambja (Nudibranchia: Polyceridae: Nembrothinae) from southern Brazil. Journal of the Marine Biological Association of the United Kingdom $85,979-984$.

Rios E.C. (1985) Seashells of Brazil. Rio Grande: Fundação Universidade do Rio Grande, Museu Oceanografico, 329 pp.

Rios E.C. (1994) Seashells of Brazil. 2nd edition. Rio Grande: Fundação Universidade do Rio Grande, Museu Oceanografico, 368 pp.

Rios E.C. (2009) Compendium of Brazilian eea shells. Rio Grande: Universidade Federal do Rio Grande, Museu Oceanográfico.

Rosenberg G. (2009) Malacolog 4.1.1: a database of western Atlantic marine Mollusca. [WWW database (version 4.1.1)]. Available at: URL http://www.malacolog.org/ (accessed 12 August 2012).

Rosenberg G. (2013) Corambe evelinae Er. Marcus, 1958. World Register of Marine Species. Available at: http://www.marinespecies.org/aphia. php? $\mathrm{p}=$ taxdetails\&id $=532660$ (accessed 12 August 2012).

Schrödl M. and Wägele H. (2001) Anatomy and histology of Corambe lucea Marcus, 1959 (Gastropoda, Nudibranchia, Doridoidea), with a discussion of the systematic position of Corambidae. Organisms Diversity and Evolution 1, 3-16.

Silva F.V., Meirelles C.A.O. and Matthews-Cascon H. (2013) A new species of Marionia (Opisthobranchia: Nudibranchia: Tritoniidae) from the tropical South Atlantic Ocean. Journal of the Marine Biological Association of the United Kingdom 93, 1617-1624.

Swennen C. and Dekker R. (1995) Corambe batava Kerbert, 1886 (Gastropoda: Opisthobranchia), an immigrant in The Netherlands, with a revision of the family Corambidae. Journal of Molluscan Studies 61, 97-107.

Valdés Á. and Bouchet P. (1998) A blind abyssal Corambidae (Mollusca, Nudibranchia) from the Norwegian Sea, with a reevaluation of the systematics of the family. Sarsia 83, 15-20.

and

Yoshioka P.M. (1986) Competitive coexistence of the dorid nudibranchs Doridella steinbergae and Corambe pacifica. Marine Ecology Progress Series $33,81-88$.

\section{Correspondence should be addressed to:}

C.M. Cunha

Museu de Zoologia, Universidade de São Paulo

Avenida Nazaré, 481

Ipiranga, São Paulo, SP

Brazil, CEP 04263-00o

email: carlomagenta@gmail.com 